\title{
Higher education of tourism in Spain and its adaptation to the European higher education area*
}

\author{
Francisco Espasandín Bustelo** \\ Carmen Díaz Fernandez*** \\ Francisco Javier Quirós Tomás****
}

Summary: 1. Introduction; 2. European higher education area; 3. Methodology; 4. Results; 5. Discussion.

SumÁrio: 1. Introdução; 2. Área de educação superior europeia; 3. Metodologia; 4. Resultados; 5. Discussão.

KEY wORDs: European higher education area; higher education in tourism; skills and abilities; Spain; curricula.

Palavras-chave: área de educação superior europeia; educação superior em turismo; habilidades e competências; Espanha; currículo.

The international tourism system has deeply undergone structural changes in the last decades which not remain outside the subsystem higher education in tourism, especially in the European case. This article has two objectives: firstly, describes the European higher education area and the objectives, skills and subjects taught in the main Spanish universities that offer higher education in tourism. On the other hand, in the light of knowledge that researchers' descriptive models, provide experience of the implementation of European credit and thorough a deeply review of the literature on the topic higher education in tourism, to propose strategies that will enable other tourism higher education systems approach to the European reality. These policy proposals are aimed at agents and elements from higher education in tourism subsystem and they specifically include: the institutions providing education in tourism, the curriculum, the teaching methods, teachers and students.

\footnotetext{
* Article received in May e accepted in Aug. 2010.

** Associate professor. Address: Escuela Universitaria de Estudios Empresariales y Turismo. Avda. S. Francisco Javier, s/n — 41018, Sevilla, Spain. E-mail: bustelo@us.es.

*** Associate professor. Address: Escuela Universitaria de Estudios Empresariales y Turismo. Avda. S. Francisco Javier, s/n — 41018, Sevilla, Spain. E-mail: cardiaz@us.es.

**** Associate professor. Address: Escuela Universitaria de Estudios Empresariales y Turismo. Avda. S. Francisco Javier, s/n — 41018, Sevilla, Spain. E-mail: quiros@us.es.
} 
O ensino superior de turismo na Espanha e sua adaptação ao sistema europeu O sistema de turismo internacional sofreu mudanças estruturais profundas nas últimas décadas que não permanecem fora do subsistema de ensino superior de turismo, especialmente no caso europeu. Este artigo tem dois objetivos: primeiro, descrever o ensino superior europeu e os objetivos, competências e disciplinas ensinadas nas principais universidades espanholas que oferecem ensino superior em turismo. Por outro lado, à luz dos conhecimentos dos modelos descritivos dos pesquisadores, fornecer a experiência na execução de crédito europeu e uma revisão abrangente e profunda da literatura sobre o tema educação superior em turismo, para propor estratégias que permitam a outros sistemas de ensino superior de turismo abordagem à realidade europeia. As propostas políticas são destinadas a agentes e elementos do subsistema de ensino superior em turismo que incluem especificamente: instituições de formação em turismo, o currículo, os métodos de ensino, professores e alunos.

\section{Introduction}

According to WWTC (2009), and despite the situation of global recession, the international tourism industry employed more than 235 million people worldwide in 2009; it is also expected that this figure increases to $303,019,000$ jobs in 2010 and that in 20201 in 10.9 jobs will be generated by the tourism industry. During 2005, the Spanish international tourism receipts amounted to US $\$ 38,495$ million, with to receipt per arrival of US $\$ 695$; while the value of the above mentioned indicators in case of Brazil promotes US $\$ 3,104$ million of international tourism receipts where, with to receipt per arrival of US\$540 dollars (WTO, 2006b). Despite it, the expectations of future growth are especially favorable for Brazil, waiting for a strong impulse in his numbers with the celebration of the World Cup of Soccer in 2014 and the Olympics in 2016 in Rio de Janeiro.

These data, reflecting the international economic importance of tourism, are due to multiple causes, and there is no doubt that one of the most important ones, is related to the major structural changes undertaken, not only by the international tourism industry, but also by the whole international tourist system.

The subsystem higher education in tourism has not remained aware to these changes. At present, the said subsystem, particularly in Europe, is undergoing a process of adaptation and change to the new demands of a global stage characterized by important changes in the labour market, an increasing global competition, continuous technological advances, changes in demand patterns - students want a high probability of employability and employers 
want employees with a high level of training — and by the requirements of the European higher education area.

The OMT (1997) considers that the subsystem higher education in tourism is a crucial element in achieving customer satisfaction and in improving competitiveness of businesses and tourist areas and, consequently, it has experienced a growing evolving process in the number of students (Airey, 2005) and the number of academic publications (Stergiou, Air and Riley, ${ }^{1} 2003$ ).

Although literature does not clarify which is emphatically the very moment of the studies in tourism, ${ }^{2}$ it is clear that education in tourism has its origins in Europe, then it is spread to the United States and Canada, and then to Australia and New Zealand (Jenkins, 1997). This situation justifies, at least partially, the fact that the current international education in tourism is influenced by Europeans and Americans. This recent origin of tourism education does not preclude its great development in the second half of the twentieth century (Fayos-Sola, 1997), at the time that mass tourism or "Fordist tourism" appears.

Although university studies on higher education in tourism are relatively new, much debate on this issue has produced in the last decade. This particular debate, according to Cervera and Ruiz-Molina (2008), is summed up in five main areas of research: the lack of agreement on the content of the curricula of tourism, which is expressed in the debate over the value of general subjects (King, McKercher, and Waryszak, 2003) versus specific ones (Dale and Robinson, 2001), the consequences of labour mobility in tourism; the informal links between tourism industry and academic research, which prevent the effective transfer of knowledge (Cooper, 2006); the importance and implementation of cooperative education in tourism studies (Leslie and Richardson, 2000) and the need for a transnational debate when it comes to educational issues in tourism in the context of emerging international content of curriculum and the global distribution of graduates from tourism. In the

\footnotetext{
1 "It had an expansion of academic articles and texts on the subject of tourism education, ranging from general texts such as Cooper et al. (1994), curriculum studies such as Stear (1981), and reviews of tourism education programmes such as Parsons (1991). There are also currently three journals that specifically cater for educational issues in the field (Journal of Hospitality and Tourism Education, Journal of Teaching in Travel and Tourism, Journal of Hospitality, Leisure, Sport, and Tourism Education)."

2 The origins are uncertain since they differ depending upon the reference writer. So, Gillespie and Baum (2001) placed the first studies in tourism in the late nineteenth century, Jafari (1990) in 1930; Majó (2004) in 1940.
} 
same vein, Airey (2003) argues that higher education in tourism has been interested in aspects such as curriculum and planning, stakeholder approaches to curriculum design and teaching or knowledge transfer in tourism higher education, the interface between tourism industry and provision of tourism higher education as well as the dilemmas of future trends in tourism higher education.

This article is intended to accomplish two main objectives: first, to know the most important features of the European higher education area and the state of higher education in tourism in the Spanish university and, secondly, by reference to prior knowledge and the review of the literature on higher education in tourism, proposing strategies to the approximation of other subsystems of higher education in tourism to the European model of higher education in tourism.

The structure of the article is based on the following pillars: first, it describes the European higher education area; second, it describes the methodology used to design the formats for higher education in tourism in the Spanish university and it presents the results obtained in terms of objectives, skills and subjects; third, we present the conclusions; fourth, strategic proposals are presented, limitations and lines of research.

\section{European higher education area}

Europe is undergoing a major transformation of higher education structures. The use of competencies as a common standard to describe the courses and educational activities is one of the pieces of a complex puzzle of initiatives to achieve the establishment of a common European higher education area (EHEA).

The training of skilled manpower that will meet the demand of the tourism sector, especially at university level, has been mainly covered in Spain to date by means of the degree of tourism. This diploma is currently undergoing a transformation due to the creation and entry into force of the European higher education area.

This transformation has its origin in 1999, when 29 European countries signed a political compromise (the Bologna Declaration) that integrates principles, objectives and commitments towards the European higher education area (EHEA) in 2010. At present, the process involves 46 European countries and 805,472,648 citizens. Using a business analogy, Ritzer (1996) considers this as a "McDonaldization" of European higher education. 
The purpose of this process is simply to put Europe at the pinnacle of the knowledge society, for the process that aims to achieve the following objectives: to improve mobility, to promote transparency and comparability, to promote cooperation and to increase quality in higher education, to strengthen social cohesion and to reduce social inequalities (Bergen Communiqué, 2005).

The actual and expected results of this process are diverse and range and they are specifically these ones:

v Proposal for a wide variety of standards, policies and initiatives;

- Appearance of new frameworks for transnational collaboration among researchers and educational institutions;

- Increase of shared knowledge and European competitiveness globally; Bologna really is a political tool to gain knowledge and global power.

Within a few years (during 2012-2013), the first new university students in the degree of tourism will start coming to market. This new degree will assume, as a general rule, an increase in the level of knowledge of students, as well as an increase of the length of the time of studies required up to three or four academic years.

The Declaration of Sorbonne, in 1998, appears for the first time the concept of European higher education area (Framework Document, 2003). Subsequently, the Bologna Declaration urges member states to adopt a system of readable and comparable degrees with the adoption of a supplement to the title, to establish a system of qualifications based on two main cycles, to establish a common system of credits (ECTS o Transfer European Credits System) in order to promote the comparability of studies and the mobility of students a graduates, to promote European cooperation and to promote the European dimension of higher education (Bologna, 1999). Finally, the Statement of Prague introduces three additional lines: learning throughout life, as essential for competitiveness, the active role of universities in the development of convergence and the promotion of the attractiveness of European higher education area ensuring superior quality, accreditation and certification (Prague, 2001).

Alter a detailed analysis of the higher education situation in the various countries of the European Union; an agreement has been reached with the recommendation of a number of parameters for higher education at European level (see table 1). 
Table 1

Parameters or university education at European level

\begin{tabular}{|lccc|}
\hline Academic year & EU data & Average values & $\begin{array}{c}\text { Values proposed } \\
\text { for Spain }\end{array}$ \\
\hline Weeks/year & $34-40$ & $37 \pm 3$ & 40 \\
Hours/week & $40-42$ & $41 \pm 1$ & 40 \\
Hours/year & $1,400-1,680$ & $1,540 \pm 140$ & 1,600 \\
Credits/year & 60 & 60 & 60 \\
Credits/week & $1.7-1.5$ & $1.6 \pm 0.1$ & 1.5 \\
Hours/credit & $25-30$ & $27.5 \pm 2.5(9 \%)$ & $25-30$ \\
\hline
\end{tabular}

Source: Crue (2002).

A university course should have a total of weeks from 34 to 40, with an average of 41 hours of work by the student each week. As a whole it would mean from 1,400 to 1,600 hours of work/study per academic year. This time is divides among a total of 60 year credits from 25 to 30 hours each.

In the case of Spain, and therefore the university tourism studies, it has been settled 40 weeks per academic year, with 40 hours of study in a week per student, distributed among 60 credits, totaling 1,600 hours per academic year.

Training in the European higher education area is not centred, as it has usually been in Spain, in the theoretical knowledge acquired by students but the overall volume of work undertaken by students during their training period.

The reference axis of the curricula becomes, therefore, the actual student learning process. The new degrees should be designed according to professional profiles, by means of a national and European perspective, and goals that should make a explicit mention of generic skills, and specific cross (knowledge, skills and abilities) that it is intended to be acquired by students throughout their studies (Framework Document, 2003).

\section{Methodology}

In order to analyze tourism university studies in Spain, within the framework set by the European Union, it has been carried out the analysis of the data in three areas: their objectives, the abilities to be developed and the curricula. 
The analysis has been focus on five of the 80 Spanish universities offering courses for the acquisition of a university degree in tourism. The universities selection process has been based on two main criteria: the scholarly contributions to 11 hospitality and tourism refereed journals and the importance of international tourism in the region where the university is.

The first criterion uses a World Ranking of the Top 100 Hospitality and Tourism Programs from an article that provides an analysis of scholarly contributions to 11 hospitality and tourism refereed journals for the years 2002 to 2006. It presents the top 100 programs as ranked by instances of publications across 11 journals for a recent 5 year period. (Severt et al., 2009). Among the 100 largest programs are those in several Spanish universities.

Regarding the second criterion, it is assumed that six Spanish regions (Catalonia, the Balearic Islands, Andalusia, Valencia, and Madrid) monopolizes the $90.1 \%$ of foreign tourists in 2006 (IET, 2006).

Taking into account both criteria, five Spanish universities have been selected: those of Las Palmas de Gran Canaria, Valencia, Balearic Islands, Alicante and Seville, all of them placed in one of the six main regions receiving international tourism. Las Palmas de Gran Canaria in the Canary Islands (9.6 million international tourists in 2006), Valencia and Alicante in the Comunidad Valenciana (5.5 million), Baleares in the Balearic Islands (10.1 million) and Seville in Andalusia (8.5 million).

Of these five universities, three, Seville, Baleares and Las Palmas de Gran Canaria, have already adopted new curricula adapted to the ECTS system. The first two have implemented these plans in the 2009/10 academic year, while the University of Las Palmas is planning to implement it during 2010/11. The remaining two universities, Valencia and Alicante, have not yet adopted their new curricula. Therefore, their data are those of the former degree, the one that is still been given.

\section{Results}

Based on data for the five universities to study, three issues are discussed below relating to the training of university students of tourism. These are:

v Aims to get to university studies in tourism;

- The skills that students should develop during their time at the university;

v The different matters to study and the importance of each one. 


\section{The aims of the studies in tourism in the Spanish university}

Each of the centers giving tourism university degrees sets its own goals. Among those analyzed by the centers, four stand out for their importance, starting with the main one.

- Students professional and/or academic training; refers to the training of highly qualified personnel to carry out their job tasks in the tourist sector directly or in any other economic activity related to tourism and leisure in general.

v Providing tools to meet the demand of the labour market.

v The acquisition of skills; refers to that graduates must have a series of both general and specific skills that will serve as a link between acquired skills and their application in the job world (Project Tunning, 2003).

- The knowledge of languages. as a target, seeks to enable to work in enterprises or agencies in other countries, as well as in Spanish entities and institutions that provide services to foreign tourists.

\section{Skills to be developed by students}

The skills have been defined by various authors as McClelland (1973), Boyatzis (1982), Greespan and Driskoll (1997), Le Boterf (2000, 2001), Levy-Levoyer $(1999,2003)$ etc. Therefore, Le Boterf (2000) defines them as the sum of knowledge, know-how and knowledge to be or the application of theoretical knowledge into professional practice. The competent person is the one that knows how to manage professional situations of high complexity.

At the university level, skills are of two types: transverse or generic and specific. The first one refers to the upbringing of the university student in the generic sense, while the specific ones are defined as the set of knowledge and scientific, technical and cultural resources directly related to the position for which the student is being formed (Aneca, 2004).

For their study the starting point will be the skills set up for the degree of bachelor in tourism by the National Agency of Quality Assessment and Accreditation in its White Book, analyzing the importance given to them by the different universities under consideration when discussing the topic of the skills that students should acquire during their university studies in tourism. 


\section{Transverse or generic skills of graduates in tourism}

Transverse or generic skills are grouped into three categories: instrumental, personal and systemic (Aneca, 2004). The relevant skills are contained in the following list.

1. Instrumentals:

v Ability to analyze and synthesize;

- Ability to organize and to plan;

- Oral and written communication in native language;

- Knowledge of a foreign language;

v Computer skills related to field of study;

$\checkmark$ Ability to manage information;

$\checkmark$ Troubleshooting;

$\checkmark$ Decision making.

2. Personals:

$\checkmark$ Teamwork;

v Working in an interdisciplinary team;

v Working in an international context;

v Skills in interpersonal relationships;

- Recognition of diversity and multiculturalism;

v Critical thinking;

$\checkmark$ Ethical commitment.

3. Systemic:

v Autonomous apprenticeship;

vitting to new situations;

- Creativity;

$\checkmark$ Leadership;

v Knowledge of other cultures and customs; 
v Initiative and entrepreneurial spirit;

v Motivation for quality;

v Sensitivity to environmental issues.

Among them, the analyzed tourism schools that have adapted themselves to the European higher education area stand out the followings: Ability to manage the information from the instrumentals, the ability to work in an interdisciplinary team and work capacity in an international context from personals, and the ability to adapt to new situations and knowledge of other cultures and customs from the systemic.

Skills such as leadership, initiative and entrepreneurial spirit, or creativity are not mentioned among the generic skills of new tourism curricula in the three analyzed universities.

In general, dealing with generic skills, it concludes that, when it comes to assessing the impact of generic or transversal skills, a consensus tends to be reached. In the specific case of tourism studies, they have, as a main characteristic, their multidisciplinary nature (business administration, economics, geography, law, history, languages, computers etc.), multidisciplinary and transdisciplinary. So, the student should be able to cope with the knowledge of various sciences, as well as the actual practice of the post is determined by the need to face the problems of managing people, companies and institutions (Aneca, 2004).

\section{Graduate of tourism specific skills}

The specific skills can be defined as the set of knowledge and scientific, technical and cultural resources that are required in direct relationship to the position that is being analyzed (Aneca, 2004). These types of skills are rooted in three types of knowledge that can be worked.

a) Learning a knowledge: knowledge based on facts, rules, concepts, theories. Information needed to know how reality is and to deal with it.

b) Learning to do: knowledge referred to a set of steps, rules and actions to achieve a result: "Knowledge in doing something."

c) Learning to develop attitudes: knowledge concerning the attitudes and reflected in the matrix of "cross-cutting skills." 
In terms of them, information related to each specific skill can be segmented in two types of knowledge: disciplinary knowledge (knowledge) and professional knowledge (know-how).

The expression of the specific skills for the degree in tourism, following the White Book, should be settled in terms of educational objectives that clearly show the learning needs of a transversal type.

The specific skills for the degree in tourism are 32 and they are contained in the following list (Aneca, 2004).

1. Understanding the principles of tourism: its spatial, social, cultural, legal, political, labour and economical dimension.

2. Analysing the economic dimension of tourism.

3. Understanding the dynamic and evolutional nature of tourism and new leisure society.

4. Knowing the main tourist political and administrative structures.

5. Turning an empirical problem to a research and draw conclusions.

6. Having a strong customer service orientation.

7. Identifying the main tourist agents.

8. Assessing the tourism potentials and the prospective analysis of its operation.

9. Analyzing, synthesizing and critically summarising the finances and assets economical information of the tourism organizations.

10. Managing financial resources.

11. Defining objectives, strategies and trade policies.

12. Leading and managing (management) the different kinds of tourism organizations.

13. Managing communication techniques.

14. Understanding the legal framework governing tourism activities.

15. Working in English as a foreign language.

16. Communicating orally and in writing in a second foreign language.

17. Communicating orally and in writing in a third foreign language.

18. Identifying and managing tourist areas and destinations. 
19. Managing tourist region in accordance with the sustainable principles.

20. Knowing the operating procedure of the field of housing.

21. Knowing the operating procedure of the field of restoration.

22. Acquiring knowledge in the field of operational procedures of brokerage firms.

23. Analyzing the impacts generated by tourism.

24. Analyzing and using information and communication technologies (ICT) in various areas of the tourism sector.

25. Understanding a public plan and the opportunities that arise for the private sector.

26. Planning and managing human resources of tourism organizations.

27. Understanding the operation of the destinations, tourism structures and their business sectors worldwide.

28. Knowing the objectives, strategies and public tools of planning.

29. Working in different sociocultural environments.

30. Knowing the main initiatives valuing the cultural heritage.

31. Understanding the characteristics of cultural heritage management.

32. Identifying needs for technical planning of infrastructure and tourist facilities.

Among them, the analyzed universities highlight seven skills. Competence in assessing the tourism potentials and the prospective analysis of its operation (\# 8), competence in leading and managing (management) the different kinds of tourism organizations (\# 12), Competence in identifying and managing tourist areas and destinations (\# 18), Competence in knowing the operating procedure of the field of housing (\# 20) and in restoration (\# 21), acquiring knowledge in the field of operational procedures of brokerage firms (\# 22) and the competence in planning and managing human resources of tourism organizations (\# 26).

These features are mainly related to knowledge from the area of business administration and marketing, which, as we shall see later, is the area of knowledge that focuses a bigger amount of credits, not only for compulsory subjects but also for optional subjects in the degree of tourism. 
On the other hand, it is to highlight the lack of importance given to skills related to customer service orientation, to the value of cultural heritage, to the understanding of legal framework governing tourism activities or to the knowledge of political and administrative structures.

\section{Areas and subjects scope of studies degree}

In the five analyzed universities, the number of credits to obtain the degree varies from a minimum of 180 credits and a maximum of 240. It should be noted that the two universities with the fewer credits, Valencia and Alicante, are those had have not yet adjusted their curricula to the European Transfer System. The length of the studies is three courses in both. However, the three universities that have already adapted their degree of tourism to the European higher education area the length of them has become four years and 240 total credits, spread out 60 credits per academic year, according to the agreed parameters for university/higher education at an European level (see table 1).

Table 2

Credits for university degree in tourism

\begin{tabular}{|c|c|c|c|c|c|c|c|}
\hline \multirow[b]{2}{*}{ University } & \multirow[b]{2}{*}{$\begin{array}{l}\text { Total } \\
\text { credits }\end{array}$} & \multicolumn{2}{|c|}{ Compulsory credits } & \multicolumn{2}{|c|}{ Optional credits } & \multicolumn{2}{|c|}{ Practicum credits } \\
\hline & & Credits & $\begin{array}{l}\text { Percentage } \\
(\%)\end{array}$ & Credits & $\begin{array}{l}\text { Percentage } \\
(\%)\end{array}$ & Credits & $\begin{array}{c}\text { Percentage } \\
(\%)\end{array}$ \\
\hline Alicante & 206.5 & 171 & 82.8 & 25.5 & 12.3 & 10 & 4.8 \\
\hline Valencia & 180 & 111 & 61.7 & 54 & 30.0 & 15 & 8.3 \\
\hline Sevilla & 240 & 192 & 80.0 & 42 & 17.5 & 6 & 2.5 \\
\hline Islas Baleares & 240 & 186 & 77.5 & 30 & 12.5 & 24 & 10.0 \\
\hline $\begin{array}{l}\text { Las Palmas de } \\
\text { Gran Canaria }\end{array}$ & 240 & 154 & 64.2 & 62 & 25.8 & 24 & 10.0 \\
\hline
\end{tabular}

Source: Curricula.

The credits are distributed among compulsory subjects, optional subjects and practical. The first, given the importance attached to its subject matter to achieve the objectives set forth in the preceding paragraph, must be reviewed and approved on a mandatory basis for all students, some of which are common to all degree in tourism in Spain and other are not. These subjects are 
those that confer the homogeneity of the university degree in tourism, both in a national and in an university level. Their percentage varies from $64.2 \%$ to $84.8 \%$ of credits (see table 2 ).

The optional subjects are complementary to the compulsory ones and each student can choose those that they could think more convenient in order to gain greater expertise in a field or specific area. They are divided into two groups: those taught in the university itself (optional subjects) and those taught in other schools in the same or another university (optional credits). Their weight range from $12.3 \%$ to $30 \%$.

The practices, in turn, refer to two concepts: the practicum and the final degree work. The practicum is required practices that the student must perform in tourist companies outside the university, while the final degree work is a serie of exercises to perform mandatory to display the acquired knowledge and skills in tourism by students at the end of their studies. Its weight varies between $2.5 \%$ and $10 \%$

All the credits are distributed among a variable number of subjects. These range from a low of 44 at the University of Las Palmas de Gran Canaria to the maximum of 57 at the University of the Islas Baleares. It also must be added to these the possibility that a student decides to study other subjects taught at other schools or degree in their choice of free elective subjects (see table 3).

Table 3

Number of subjects by the university

\begin{tabular}{|lccc|}
\hline Universidad & Total subjects & $\begin{array}{c}\text { Compulsory } \\
\text { subjects }\end{array}$ & Optional subjects \\
\hline Alicante & 47 & 30 & 17 \\
Valencia & 49 & 19 & 30 \\
Sevilla & 48 & 42 & 15 \\
Islas Baleares & 57 & 35 & 22 \\
Las Palmas de Gran Canaria & 44 & 34 & 10 \\
\hline
\end{tabular}

Source: Curricula.

For an adequate analysis of the subject contents they are grouped by areas of expertise. The areas of knowledge taught in the school of tourism analyzed are the 12 following:

v Management and marketing; 
- Accounting and finance;

$\checkmark$ Law;

vathematics and statistics;

- Economy;

v Philology (languages);

- Geography, history, art, archaeology, and cultural heritage;

v Psychology, sociology, philosophy, and anthropology;

- Computers;

$\checkmark$ Ecology;

v Biochemistry, molecular biology, nutrition, and food science;

v Architectural buildings.

The weight of the various areas of expertise differs so much among themselves as among the curricula of various universities analyzed. The data for this information are collected in the four tables below. In the first, table 4, it is shown the average weight on the number of credits for each of the areas for college. The second one (table 5) presents the weighted average, maximum, minimum and standard deviation for each of the areas. In the third, table 6, we find the same information as in the first, but, in this case, related to the compulsory credits, while the fourth, table 7 , collects the same data, but related to the optional subjects.

The importance of various areas of knowledge is very diverse. Analyzing the weighting of each in terms of the credits assigned to the subjects in each area (table 4), it can be seen that the most compelling subject is business management and marketing, with an average of $26.7 \%$, ranging from a minimum of $19 \%$ in the case of the University of Alicante to $30.8 \%$ in the case of the Islas Baleares.

Table 4

Credits per area of knowledge. All subjects

\begin{tabular}{|lcccccc|}
\hline University & Media & Alicante & Valencia & Sevilla & Baleares & Canarias \\
\hline \multirow{2}{*}{ Management and marketing } & 71.4 & 48 & 57 & 90 & 96 & 66 \\
& $26.7 \%$ & $19.0 \%$ & $23.6 \%$ & $29.8 \%$ & $30.8 \%$ & $28.9 \%$ \\
\hline
\end{tabular}




\begin{tabular}{|lcccccc|}
\hline University & Media & Alicante & Valencia & Sevilla & Baleares & Canarias \\
\hline Accounting and finance & 23.7 & 12 & 28.5 & 18 & 36 & 24 \\
& $8.9 \%$ & $4.8 \%$ & $11.8 \%$ & $6.0 \%$ & $11.5 \%$ & $10.5 \%$ \\
Law & 29.7 & 24 & 22.5 & 36 & 42 & 24 \\
Mathematics and statistics & $11.1 \%$ & $9.5 \%$ & $9.3 \%$ & $11.9 \%$ & $13.5 \%$ & $10.5 \%$ \\
& 6.4 & 0 & 0 & 8 & 18 & 6 \\
Economy & $2.4 \%$ & $0.0 \%$ & $0.0 \%$ & $2.6 \%$ & $5.8 \%$ & $2.6 \%$ \\
Philology & 30 & 31.5 & 52.5 & 30 & 30 & 6 \\
Geography, history, art and & $11.2 \%$ & $12.5 \%$ & $21.7 \%$ & $9.9 \%$ & $9.6 \%$ & $2.6 \%$ \\
archaeology & 35.7 & 48 & 22.5 & 42 & 36 & 30 \\
Psychology, sociology, & $13.4 \%$ & $19.0 \%$ & $9.3 \%$ & $13.9 \%$ & $11.5 \%$ & $13.2 \%$ \\
philosophy and anthropology & 38.7 & 46.5 & 27 & 54 & 30 & 36 \\
& $14.5 \%$ & $18.5 \%$ & $11.2 \%$ & $17.9 \%$ & $9.6 \%$ & $15.8 \%$ \\
Computers & 14.1 & 15 & 31.5 & 12 & 0 & 12 \\
& $5.3 \%$ & $6.0 \%$ & $13.0 \%$ & $4.0 \%$ & $0.0 \%$ & $5.3 \%$ \\
Ecology & 8.7 & 13.5 & 0 & 12 & 6 & 12 \\
Biochemistry, molecular & $3.3 \%$ & $5.4 \%$ & $0.0 \%$ & $4.0 \%$ & $1.9 \%$ & $5.3 \%$ \\
biology, nutrition and food & 6.9 & 4.5 & 0 & 0 & 18 & 12 \\
science & $2.6 \%$ & $1.8 \%$ & $0.0 \%$ & $0.0 \%$ & $5.8 \%$ & $5.3 \%$ \\
Architectural buildings & 0.9 & 4.5 & 0 & 0 & 0 & 0 \\
Total & $0.3 \%$ & $1.8 \%$ & $0.0 \%$ & $0.0 \%$ & $0.0 \%$ & $0.0 \%$ \\
& 0.9 & 4.5 & 0 & 0 & 0 & 0 \\
Source & $0.3 \%$ & $1.8 \%$ & $0.0 \%$ & $0.0 \%$ & $0.0 \%$ & $0.0 \%$ \\
& 267.1 & 252 & 241.5 & 302 & 312 & 228 \\
& $100.0 \%$ & $100.0 \%$ & $100.0 \%$ & $100.0 \%$ & $100.0 \%$ & $100.0 \%$ \\
\hline
\end{tabular}

Source: Curricula.

Following this knowledge area, there is a group of four with values ranging between $11 \%$ and $15 \%$. These are, in order of weighting: 2 nd in geography, history, art, archaeology, philology; 3rd, law; 4th and 5th economics. The importance of each one varies again among universities. Thus, the minimum is reached for the area of business in the Islas Canarias $(2.6 \%)$ and the maximum for the same area as well in Valencia (21.7\%). The sixth important area is accounting and finance, with an average weight of $8.9 \%$, ranging from $4.8 \%$ at the University of Alicante and $11.8 \%$ of that of Valencia.

Finally, five areas of knowledge do not exceed a weighted average of $6 \%$. These are: computers, psychology, sociology, philosophy and anthropol- 
ogy, mathematics and statistics, ecology, biochemistry, molecular biology, nutrition and food science, and architectural constructions. In all of them at least one of the universities surveyed did not include them in their curriculum. This is the case in the areas of computer science, psychology, sociology, philosophy and anthropology and the Universities of Valencia and the Islas Baleares, respectively. Knowledge of mathematics and statistics and the ecology, each of them, are not taken into account by two of the universities analyzed, as long as biochemistry, molecular biology, nutrition and food science and architectural constructions, each one, are only included in one plan.

If we analyze the deviations from the mean among universities and knowledge areas (see table 5), we can see that the greatest deviation occurs in the area of knowledge of economics, with a value of 6.9, followed by business administration and marketing with a 4.98; and psychology, sociology, philosophy and anthropology with a 4.73 , although it should be pointed out that the deviation in the case of business administration and marketing from the mean value it is produced related to the higher average value among the various areas of knowledge.

Tabela 5

Descriptive statistics credits by area of knowledge

\begin{tabular}{|lcccrc|}
\hline Area of knowledge & N & Minimum & Maximum & Media & Stand. dev. \\
\hline Business administration and & 5 & 19.05 & 30.77 & 26.4336 & 4.97560 \\
marketing & 5 & 4.76 & 11.80 & 8.9176 & 3.30862 \\
Accounting and finance & 5 & 9.32 & 13.46 & 10.9498 & 1.74146 \\
Law & 5 & .00 & 5.77 & 2.2100 & 2.38782 \\
Mathematics and statistics & 5 & 2.63 & 21.74 & 11.2840 & 6.89674 \\
Economy & 5 & 9.32 & 19.05 & 13.3936 & 3.61765 \\
Philology & 5 & 9.62 & 18.45 & 14.5836 & 3.98622 \\
Geography, history, art and ar- & & & & & \\
chaeology & 5 & .00 & 13.04 & 5.6465 & 4.73386 \\
$\begin{array}{l}\text { Psychology, sociology, philosophy } \\
\text { and anthropology }\end{array}$ & 5 & .00 & 5.36 & 3.3034 & 2.30897 \\
Computers & 5 & .00 & 5.77 & 2.5636 & 2.79790 \\
Ecology & 5 & .00 & 1.79 & .3571 & .79860 \\
Biochemistry, molecular biology, & 5 & .00 & 1.79 & .3571 & .79860 \\
nutrition and food science & 5 & & & & \\
Architectural buildings & 5 & & & \\
N valid (as list) & & &
\end{tabular}

Continues 
To see the importance of various areas of knowledge in the curriculum of a university degree in tourism is insufficient to make a study on the total weight of each one of them. This study should extend to differences among core subjects, whose importance is considered greater, and among the electives, which serve as a means of specialization of students in specific segments related to future jobs to perform after finishing college.

A first view relates to the knowledge of business administration and marketing. This area occupies the first position not only among the optional subjects but also among compulsory ones for all the analyzed universities.

When comparing the values obtained for the subjects (table 6) with those of all the college credits, it can be seen that the order of importance is constant except in the case of the studies of language (philology) that rises one position ahead of geography, history, art and archaeology, although their values are close both in one and the other case and less than $2 \%$ of credits.

Table 6

Credits for area of knowledge. Compulsory subjects

\begin{tabular}{|lrrrrrr|}
\hline University & Media & Alicante & Valencia & Sevilla & Baleares & Canarias \\
\hline Administration and marketing & 48.3 & 34.5 & 21 & 78 & 54 & 54 \\
& $27.6 \%$ & $18.7 \%$ & $18.9 \%$ & $36.8 \%$ & $29.0 \%$ & $30.0 \%$ \\
Accounting and finance & 12 & 12 & 6 & 0 & 24 & 18 \\
Law & $6.9 \%$ & $6.5 \%$ & $5.4 \%$ & $0.0 \%$ & $12.9 \%$ & $10.0 \%$ \\
Mathematics and statistics & 18.6 & 24 & 9 & 24 & 24 & 12 \\
& $10.6 \%$ & $13.0 \%$ & $8.1 \%$ & $11.3 \%$ & $12.9 \%$ & $6.7 \%$ \\
Economy & 4 & 0 & 0 & 8 & 6 & 6 \\
Philology & $2.3 \%$ & $0.0 \%$ & $0.0 \%$ & $3.8 \%$ & $3.2 \%$ & $3.3 \%$ \\
Geography, history, art and & 23.4 & 31.5 & 25.5 & 30 & 24 & 6 \\
archaeology & $13.4 \%$ & $17.1 \%$ & $23.0 \%$ & $14.2 \%$ & $12.9 \%$ & $3.3 \%$ \\
Psychology, sociology, & 26.4 & 30 & 18 & 30 & 30 & 24 \\
philosophy and anthropology & $15.1 \%$ & $16.3 \%$ & $16.2 \%$ & $14.2 \%$ & $16.1 \%$ & $13.3 \%$ \\
Computers & 26.1 & 28.5 & 18 & 36 & 18 & 30 \\
& $14.9 \%$ & $15.4 \%$ & $16.2 \%$ & $17.0 \%$ & $9.7 \%$ & $16.7 \%$ \\
& 6.3 & 6 & 13.5 & 0 & 0 & 12 \\
& 5.1 & 13.5 & 0 & 6 & 0 & 6 \\
& $2.9 \%$ & $7.3 \%$ & $0.0 \%$ & $2.8 \%$ & $0.0 \%$ & $3.3 \%$ \\
\hline
\end{tabular}




\begin{tabular}{|lrrrrrr|}
\hline University & Media & Alicante & Valencia & Sevilla & Baleares & Canarias \\
\hline Ecology & 4.5 & 4.5 & 0 & 0 & 6 & 12 \\
Biochemistry, molecular & $2.6 \%$ & $2.4 \%$ & $0.0 \%$ & $0.0 \%$ & $3.2 \%$ & $6.7 \%$ \\
biology, nutrition and food & 0 & 0 & 0 & 0 & 0 & 0 \\
science & $0.0 \%$ & $0.0 \%$ & $0.0 \%$ & $0.0 \%$ & $0.0 \%$ & $0.0 \%$ \\
Architectural buildings & 0 & 0 & 0 & 0 & 0 & 0 \\
& $0.0 \%$ & $0.0 \%$ & $0.0 \%$ & $0.0 \%$ & $0.0 \%$ & $0.0 \%$ \\
Total & 174.7 & 184.5 & 111 & 212 & 186 & 180 \\
& $100.0 \%$ & $100.0 \%$ & $100.0 \%$ & $100.0 \%$ & $100.0 \%$ & $100.0 \%$ \\
\hline
\end{tabular}

Source: Curricula.

In the case of the optional subjects the differences are greater, as shown in table 7. Both the first two areas as the last five maintain their relative positions, but changes occur in the range of the five intermediate (post 3 to 7). So, accounting and finance improves three seats and as much law as psychology, sociology, philosophy and anthropology one. Those that lose seats are philology, two seats, and economics, three.

\section{Table 7}

\section{Credit for area of knowledge. Optional subjects}

\begin{tabular}{|lrrrrrr|}
\hline University & Media & Alicante & Valencia & Sevilla & Baleares & Canarias \\
\hline \multirow{2}{*}{ Administration and marketing } & 23.1 & 13.5 & 36 & 12 & 42 & 12 \\
& $25.0 \%$ & $20.0 \%$ & $27.6 \%$ & $13.3 \%$ & $33.3 \%$ & $25.0 \%$ \\
Accounting and finance & 11.7 & 0 & 22.5 & 18 & 12 & 6 \\
Law & $12.7 \%$ & $0.0 \%$ & $17.2 \%$ & $20.0 \%$ & $9.5 \%$ & $12.5 \%$ \\
Mathematics and statistics & 11.1 & 0 & 13.5 & 12 & 18 & 12 \\
& $12.0 \%$ & $0.0 \%$ & $10.3 \%$ & $13.3 \%$ & $14.3 \%$ & $25.0 \%$ \\
Economy & 2.4 & 0 & 0 & 0 & 12 & 0 \\
Philology & $2.6 \%$ & $0.0 \%$ & $0.0 \%$ & $0.0 \%$ & $9.5 \%$ & $0.0 \%$ \\
Geography, history, art and & 6.6 & 0 & 27 & 0 & 6 & 0 \\
archaeology & $7.1 \%$ & $0.0 \%$ & $20.7 \%$ & $0.0 \%$ & $4.8 \%$ & $0.0 \%$ \\
& 9.3 & 18 & 4.5 & 12 & 6 & 6 \\
& $10.1 \%$ & $26.7 \%$ & $3.4 \%$ & $13.3 \%$ & $4.8 \%$ & $12.5 \%$ \\
& 12.6 & 18 & 9 & 18 & 12 & 6 \\
& $13.6 \%$ & $26.7 \%$ & $6.9 \%$ & $20.0 \%$ & $9.5 \%$ & $12.5 \%$ \\
\hline
\end{tabular}




\begin{tabular}{|lrrrrrr|}
\hline University & Media & Alicante & Valencia & Sevilla & Baleares & Canarias \\
\hline Psychology, sociology, philosophy & 7.8 & 9 & 18 & 12 & 0 & 0 \\
and anthropology & $8.4 \%$ & $13.3 \%$ & $13.8 \%$ & $13.3 \%$ & $0.0 \%$ & $0.0 \%$ \\
& 3.6 & 0 & 0 & 6 & 6 & 6 \\
Computers & $3.9 \%$ & $0.0 \%$ & $0.0 \%$ & $6.7 \%$ & $4.8 \%$ & $12.5 \%$ \\
& 2.4 & 0 & 0 & 0 & 12 & 0 \\
Ecology & $2.6 \%$ & $0.0 \%$ & $0.0 \%$ & $0.0 \%$ & $9.5 \%$ & $0.0 \%$ \\
Biochemistry, molecular biology, & 0.9 & 4.5 & 0 & 0 & 0 & 0 \\
nutrition and food science & $1.0 \%$ & $6.7 \%$ & $0.0 \%$ & $0.0 \%$ & $0.0 \%$ & $0.0 \%$ \\
Architectural buildings & 0.9 & 4.5 & 0 & 0 & 0 & 0 \\
& $1.0 \%$ & $6.7 \%$ & $0.0 \%$ & $0.0 \%$ & $0.0 \%$ & $0.0 \%$ \\
Total & 92.4 & 67.5 & 130.5 & 90 & 126 & 48 \\
& $100.0 \%$ & $100.0 \%$ & $100.0 \%$ & $100.0 \%$ & $100.0 \%$ & $100.0 \%$ \\
\hline
\end{tabular}

Source: Curricula.

When analyzing the differences among the standard deviations among universities for both types of subjects, it can be seen that average standard deviation is much higher among optional than among the compulsory ones and the whole range of subjects. Thus, in the group of optional subjects this value is about $6 \%$, while the other two cases is very similar and less than $3 \%$.

This is a logical fact if it is taken into account that the various universities tend to specialize more in one or another area of knowledge due to their history, economic environment and the peculiarities of the local labour market that the supply of graduates is directed to.

\section{Discussion}

In this paragraph there are offered the principal conclusions of the investigation, grouped in two big blocks: general conclusions or relative to the subsystem higher education in tourism and specific or relative to the subsystem higher education in tourism in Spain.

Between the general conclusions there are highlighted the two that continue:

v The higher education in tourism is crucial to achieve the satisfaction of the client and the progress of the competitiveness of the companies and the 
tourist regions and a process of increasing evolution has experimented on the number of students and on the number of academic publications; such is their level of importance that can be considered an investigation line in tourism;

- There is living through Europe a big transformation of his structures of higher education and, in particular, it is implanting reforms in the higher education in tourism.

On the other hand, the most excellent specific conclusions, relative to the Spanish case, are those who are mentioned next:

v The Spanish centers that give university studies in tourism fix their own targets that, by order of importance, are: the professional and/or academic training of the students, the offer of instruments to satisfy the demand of the labor market, the securing of competitions and the languages knowledge;

- Everything seems to indicate that the qualifications in tourism in Spain will have a duration of four years and 240 entire credits distributed in 60 per year according to the foreseen in the parameters agreed for the university education European level;

- The number of credits to obtain the qualifications changes between a minimum of 180 and a maximum of 240;

v Every academic course consists of 40 weeks and 1,600 working time of the pupil;

- The study plans take proper learning of the pupils as a reference point and are designed according to a few professional profiles with national and European perspective and of a few targets that must do express mention to the generic and specific competitions that try to provide the student to themselves;

v The most outstanding transverse competitions in the tourist studies that are given in the Spanish universities are: the capacity of management of the information between the sets of instruments, the working capacity in a team of character to interdisciplinary and the working capacity in an international context between the personnel and the capacity of adaptation to new situations and knowledge of other cultures and customs between the systemic ones. It is worth of mention that there do not mention competences relative to the capacity of leadership, the initiative and the enterprising spirit, or the creativity; 
- As for the specific competitions emphasizes that the student must be capable of being unrolled by knowledge that come from diverse sciences, at the time that the proper exercise of the profession is determined by the need to face the problems of persons' management, companies and institutions. The most important specific competitions in the Spanish ambience are: the aptitude to evaluate the tourist potentials and the pilot analysis of his development, the competition to direct and to manage the different types of tourist organizations, the competition to identify and to manage spaces and tourist destinations, the knowledge of the operative procedure of the ambience of accommodation, the knowledge on restoration, the knowledge on the operative procedures of the companies of intermediation and the competition to plan and to manage the human resources of the tourist organizations. On the other hand, it surprises the scarce relevancy of the capacities related to the orientation to the service to the client, the value of the cultural heritage, the comprehension of the legal frame that regulates the tourist activities or the knowledge of the political-administrative structures;

- To acquire the above mentioned competitions, the pupil must study obligatory subjects (which percentage ranges between $64.2 \%$ and $84.8 \%$ of the credits), optional subjects (your weight ranges between 12.3\% and 30\% of the credits) and the practicum and degree theses (which weight ranges between $12.5 \%$ and $10 \%$ of the whole of credits);

v The group of the above mentioned matters for knowledge areas reveals that the area of business administration and marketing is the most important, with an average percentage of $26.7 \%$ of the whole of credits; continued by four areas of knowledge, which they represent between $11 \%$ and $15 \%$ of the whole of credits (geography; history, art, archaeology, philology, economy and law); and for the area of accounting and finance, with a middleweight of $8.9 \%$ of the whole of credits. Five knowledge areas (computer science; psychology, sociology, philosophy and anthropology; mathematics and statistics; ecology; biochemistry, molecular biology, nutrition and food science; and architectural buildings) do not overcome an average weighting of 6\%;

v Finally, emphasizes that the universities analyzed, due to their own history, economic environment and the peculiarities of the local labor market towards which it goes, tend to specialize in major measurement in one or another knowledge area.

The result of the above findings, concerning the European higher education area and the experience of Spanish universities in the delivery of higher 
education in tourism, and a thorough review of the literature on higher education in tourism strategies are proposed for each elements and agents that integrate or interact with the subsystem higher education in tourism; we specifically refer to institutions providing higher education in tourism, curriculum design, teaching methods, the teacher and the student.

\section{Implications for institutions providing higher education in tourism}

As a general rule, institutions providing higher education in tourism will increase their level of market orientation and develop reengineering processes, similar to the Spanish and European sample.

The increasing of the market orientation will be achieved if teaching institutions care about: developing new and creative ways to attract, to retain and to strengthen relationships with the students; to know and to respond appropriately to the needs created by society and the economy knowledge, implement quality assurance systems based on international standards such as European Quality Improvement Programme (Equip) and to strengthen its international presence. According to Sangpikul (2009), this increased international visibility will be achieved through the following alternatives:

v Exchanges of professors in tourism studies;

- Exchanges of students in tourism studies, in the framework of EU exchange programmes, as part of other bilateral and multilateral agreements;

v International internships as part of the education programme;

v International summer schools, seminars, $\mathrm{PhD}$ workshops and conferences;

v Electronic tourism conferences;

v Electronic tourism networks, such as Trinet;

v Cooperation with international organisations (Aiest, WTO, Themis etc.); and

v The development of school specific subjects in tourism (for example, environmental economics in tourism).

The reengineering process development raises, among others, the following requirements: challenging the previous educational model, setting clear objectives for all of higher education in tourism and providing sufficient resources and capabilities to the system higher education in tourism and the social agents involved. 


\section{Implications for curriculum design in higher education in tourism}

The curriculum will be chaired by the principles of market orientation - which will involve greater participation of all social actors that make up the tourist and the subsequent consideration of their demands on higher education in tourism - and transparency, enabling, turn, the international comparison.

This design will be oriented to learning based on skills ${ }^{3}$ and it will be very conditioned to the fact that tourism, as an academic discipline, has a number of particular characteristics: his youth, his immaturity (Tribe, 2006, Westlake, 1997) and its multidisciplinary nature, and including content and methods from other social sciences as humanities, anthropology, philosophy, psychology, ecology, sociology...

The selection of training contents that will integrate the curriculum design will take into account numerous factors, among which are: other curricula successfully implemented and future directions that are expected to preside over the demands on education in tourism.

In this latter regard, Sheldon et al. (2007) reflect the views of 16 experts in tourism and identifies the values, knowledge, and capabilities that graduates will need to lead positively, responsibly and effectively on the horizon 2010-30. The responses of 16 participants were summarized and the following four categories emerged:

- Destination stewardship skills (management of real and virtual networks, knowledge sharing skills, ability to respect and work with all stakeholders, managing complex adaptive systems, environmental management skills);

v Political and ethical skills (ethical behaviour: demonstration and motivation, integration of basic human values into the workplace, lobbying and the ability to influence the political process);

- Enhanced human resource skills (team building, effective listening and negotiation, motivation and leadership, working with distributed, virtual project teams, emotional intelligence);

v Dynamic business skills (flexibility, multitasking, critical thinking, optimal use of common sense, innovation/entrepreneurship, communication skills using

\footnotetext{
${ }^{3}$ As noted by Morin (1999) "The learning skills is not just a performance-oriented educational technology skills immediately, but applies the integral education of the student, as it deals with both theoretical knowledge and practical skills or knowledge or applications and attitudes or personal commitments, ranging knowledge and know-how to learn or may be."
} 
new multimedia technologies, cross-cultural competencies, risk identification, estimation, and control, avoiding problems rather than solving them).

Educational programs are aimed at achieving a kind Tedqual tourism certification in order to achieve effective tourism programs (Sheldon et al., 2008) and, consequently, ensure the quality of education in tourism.

\section{Implications for teaching methods used in higher education in tourism}

In general, the implemented teaching methods provide a more interactive and collaborative learning. In this line, it will be increased the use of ICT and make greater use of simulation, the case method, experiential learning and the participation of tourism professionals in the classroom in order to combine theoretical knowledge with practice (Cho and Schmeltzer, 2000).

\section{Implications for teachers of higher education in tourism}

From an educational point of view, the teacher will adopt a proactive attitude towards the implementation of innovative and modern teaching methods. This should be directed to models that focus on the skills and competencies of the learner and away from teacher centred models.

Inui et al. (2006) believe that

Educators provide students with intellectual and moral leadership. Taking the natural stance, our role as educators should be in preparing students to be employable, while the theoretic stance would require educators to facilitate critical thinking and moral decision making in our students. Educators are more than skilled experts in classrooms; they are social leaders, cultural advocates, and moral visionaries, spiritual directors who choose to do their leading, advocating, visioning and directing.

Consequently we, as tourism educators, need to revisit the focus of the education that we provide for our future professionals and scholars".

On the other hand, Martin et al. (1994) raised as something predictable ("the performance of individual teachers will be assessed and evaluated by the student and future employment will depend on the score") is already a reality in much higher education in tourism. 
From a research point of view, the teacher with the financial support that make up the tourism and participation in international research teams, seek to achieve and maintain high international quality standards.

\section{Implications for students of higher education in tourism}

In the words of Baum (2006), "an imperative for students at all levels of tourism education is the understanding of the international nature of tourism products and markets".

From a research point of view, the teacher with the financial support that make up the tourism and participation in international research teams, seek to achieve and maintain high international quality standards.

The behaviour of the students will aim to discuss, debate, and draw their own conclusions and train themselves in creative thinking and independent thinking; their relationships with teachers will be democratic.

Finally, we quote the words of Rico and Padurean (2009):

Higher tourism education will increasingly be offered in countries like e.g. Brazil, China, India (...) The future will have to show whether fast growing economies will, with economic growth and a sharp rise in outgoing tourism, develop along a path similar to European countries and thus catch up with the leaders. The future will have to show whether fast growing economies will, with economic growth and a sharp rise in outgoing tourism, develop along a path similar to European countries and thus catch up with the leaders.

\section{Limitations and future lines of research}

Among the limitations of this article we highlight the following ones.

v The difficulty of accessing data in tourism studies. At the beginning researchers were aimed at an analysis of tourism studies in European universities. The attempt to collect data on goals, skills and subjects taught in European tourist studies was unsuccessful; thus, this indicates a lack of transparency on the part of the European educational institutions.

- The stated conceptual model is descriptive and it only includes aspects of goals, skills and subjects taught in higher education in tourism of the main Spanish universities. We agree with Stergiou, Air and Riley (2003) that 
the stance of this literature provides the rationale for this study. Much of the literature is uncritical and rarely challenges the status quo of tourism education (Tribe, 1999). In particular, there are three worrying aspects to the existing literature. First, so many of the points addressed are in fact a recycling of issues from the tourism literature that has been published over the years (Stergiou et al., 2002). Second, the preoccupation of authors and researchers with what is and what ought to be taught-the curriculum-has tended to drive out issues related to the conduct of teaching, to the extent that research on teaching within the field is notable mainly for its absence (Tribe, 2002). Third, and perhaps more seriously, there is little that offers insights based on the extensive literature of education (Airey, 2001). It is here that this study proposes to add a critical and philosophical perspective. This perspective seeks to address issues about the nature and the evaluation of teaching in tourism higher education by drawing upon thinking and research from education as well as from tourism.

- The research temporal horizon coincides with the present situation of higher education in tourism, that is, it presents a cross-sectional analysis of studies in tourism.

To overcome these limitations, being aware that higher education in tourism is a field of research that deserves further attention from researchers and the desire to provide value to all players that belong to international tourism system, the authors state to improve this research and for this project to widen the horizon of research space, conducting longitudinal research and designing cognitive models (descriptive and explanatory) that include variables such as: teaching methods and assessment, the role of teachers and students and, especially, the economic and social gains in higher education in tourism.

\section{References}

AIREY, D.; JOHNSON, Susan. The content of tourism degree courses in the UK. Tourism Management, v. 20, n. 2, p. 220-235, 1999.

. Growth and development. In: ; TRIBE, John (Eds.). An international handbook of tourism education. Amsterdam: Elsevier, 2005. p. 13-24.

ANECA (Agencia Nacional de Evaluación de la Calidad y Acreditación). Título de grado en turismo. Madrid: Aneca, 2004. Available at: <www.uned.es/espacio-europeo/pdf/Libro-blanco-turismo.pdf > . 
El sistema universitario español y el espacio europeo de educación superior. Available at: <www.aneca.es/modal_eval/docs/doc_conv_aneca1.pdf $>$. p. 6. Acess: Dec. 2007.

AYIKORU, M.; TRIBE, J. Enhancing the interpretive and critical approaches to tourism education enquiry through a discursive analysis. In: ATELJEVIC, I.; PRITCHARD, A.; MORGAN, N. The critical turn in tourism studies. Innovative research methodologies. Amsterdam: Elsevier, 2007. p. 29-39.

BAUM, T. Global tourism higher education: the British isles experience. In: HSU, H. C. (Ed.). Global tourism higher education: past, present, and future. New York: The Haworth Hospitality Press, NY, 2006.

BECKETT, D. Embodied competence and generic skill: the emergence of inferential understanding. Educational Philosophy and Theory, v. 36, n. 5, p. 497-508, 2004.

BOE. Resolución de 20 de julio de 2000, de la Universidad de Alicante, relativa al plan de estudios conducente a la obtención del título de diplomado en turismo, BOE, n. 188, 7 ago. 2000.

BOLONIA. Declaración de Bolonia. 19 junio 1999. Available at: <www.mec.es>.

BOYATZIS, R. E. The competent manager: a model for effective performance. New York: John Wiley \& Sons, 1982.

BRUCE, C.; GERBER, R. Towards university lecturers' conceptions of student learning. Higher Education, v. 29, n. 4, p. 443-458, 1995.

CERVERA-TAULET, A.; RUIZ-MOLINA, M. E. Tourism education: a strategic analysis model. Journal of Hospitality, Leisure, Sport and Tourism Education, v. 7, n. 2, p. 59-70, 2008.

CHURCHWARD, J.; RILEY, M. Tourism occupations and education: an exploratory study. International Journal of Tourism Research, v. 4, n. 2, p. 77-86, 2003.

COOPER, C. Knowledge management and tourism. Annals of Tourism Research, v. 33, n. 1, p. 47-64, 2006.

CRUE (Conferencia de Rectores de Universidades Españolas). El crédito europeo y el sistema educativo español. Informe Técnico de la CRUE, Madrid, 28 oct. 2002.

DALE, C.; ROBINSON, N. The theming of tourism education: a three-domain approach. International Journal of Contemporary Hospitality Management, v. 13, n. 1, p. 30-34, 2001.

DE MIGUEL, M. Cambio de paradigma metodológico en la educación superior. Exigencias que conlleva. Cuadernos de Integración Europea, n. 2, p. 16-27, 2005. 
DOCUMENTO-MARCO. La integración del sistema universitario español en el espacio europeo de enseñanza superior. Madrid: Ministerio de Educación, Cultura y Deporte, 2003.

ERNATAWI, Diyah B. Stakeholder's view on higher tourism education. Annals of Tourism Research, v. 30, n. 1, p. 255-258, 2003.

FAYOS-SOLÁ, E. Educación y formación en la nueva era del turismo: la visión de la OMT. In: (Ed.) Human capital in the tourism industry of the 21st century. Madrid: WTO, 1997. p. 59-79

GAMERO GÓMEZ, S. (Coord.). Competencias profesionales para los universitarios de la Universidad de Sevilla. Sevilla: Junta de Andalucía, Conserjería de Innovación, Ciencia y Empresa y Universidad de Sevilla, 2009.

GARCÍA MANJÓN, J. V.; PÉREZ LÓPEZ, M. C. Espacio europeo de educación superior, competencias profesionales y empleabilidad. Revista Iberoamericana de Educación, n. 46, p. 9-10, 2008.

GEE, C. Y. Tourism employment issues: the Pata viewpoint. In: WTO. Human resources in tourism: towards a new paradigm. Madrid: WTO, 2002. p. 71-78.

GOODMAN JR., Raymond. J.; SPRAGUE, Linda. The future of hospitality education: meeting the industry's needs. Cornell Hotel and Restaurant Administration Quarterly, v. 32, n. 2, p. 66-70, 1991.

HAERING-PÉREZ, F. et al. Towards the European higher education area, Bologna process, national reports 2004-2005. Direction General of Universities, Ministry of Education and Science, 2004.

HJALAGER, A-M. Global tourism careers: opportunities and dilemas facing higher education in tourism. Journal of Hospitality, Leisure, Sport and Tourism Education, v. 2, n. 2, p. 26-38, 2003.

IET. Balance de turismo en España 2006. Ministerio de Industria, Turismo y Comercio, 2006.

INUI, Y.; WHEELER, D.; LANKFORD, S. Rethinking tourism education: what should schools teach? Journal of Hospitality, Leisure, Sport and Tourism Education, v. 5, n. 2, p. 25-35, 2006.

JAFARI, J. Research and scholarship: the basis of tourism education. Journal of Tourism Studies, n. 1, p. 33-41, 1990.

JASPERS, G. International harmonisation of tourism education. Annals of Tourism Research, v. 14, n. 4, p. 580-582, 1987. 
JENKINS, C. I. Tourism educational systems, institutions and curricula: standardization and certification in human capital. In: WTO. The tourism industry of the 21st century. Madrid: WTO, 1997. p. 215-222.

KING, B.; MCKERCHER, B.; WARYSZAK, R. A comparative study of hospitality and tourism graduates in Australia and Hong Kong. International Journal of Tourism Research, v. 5, n. 6, p. 409-420, 2003.

KOUCKY, J.; MENG C.; VAN DER VELDEN, R. Reflex country study. 2007. Retrieved April 10, 2010. Available at: <www.fdewb.unimaas.nl/roa/reflex/index.htm>.

LESLIE, D.; RICHARDSON, A. Tourism and cooperative education in UK undergraduate courses: are benefits being realised? Tourism Management, v. 21, n. 5, p. 489-498, 2000.

LÉVY-LEBOYER, C. Gestión de las competencias. Barcelona: Ediciones Gestión 2000, 2003.

LUM, G. On the non-discursive nature of competence. Educational Philosophy and Theory, v. 36, n. 5, p. 486-496, 2004.

MAJÓ, J. (Ed.). Grado de turismo. 2004. Available at: <www.aneca.es/modal_eval/ docs/libroblanco_jun05_turismo.pdf>. Acess: Apr. 10, 2010.

. Competencias o capacidades profesionales que deben aportar las nuevas titulaciones al sistema turístico. In: CONGRESO NACIONAL Y I INTERNACIONAL DE ESCUELAS DE TURISMO. 60., 2005, Valladolid, Anales...

MARKOVIC. S. Expected service quality measurement in tourism higher education. Nase Gospodarstvo: NG, v. 52, n. 1/2, p. 86-95, 2006.

MORGAN, M. From production line to drama school: higher education for the future of tourism. International Journal of Contemporary Hospitality Management, v. 16, n. 2, p. 91-99, 2004.

MORIN, E. Les sept savoirs necessaires à l'éducation du future. París: Editions du Seuil, 1999.

MUNAR, A. M.; MONTAÑO, J. J. Generic competences and tourism graduates. Journal of Hospitality, Leisure, Sport and Tourism Education, v. 8, n. 1, p. 70-84, 2009.

MUNAR, A. M. Is the Bologna process globalizing tourism education? Journal of Hospitality, Leisure, Sport and Tourism Education, v. 6, n. 2, p. 68-82, 2007.

PALMER POL, A.; MONTAÑO MORENO, J. J.; PALOU OLIVER, M. Las competencias genéricas en la educación superior. Estudio comparativo entre la opinión de empleadores y académicos. Psicothema, v. 21, n. 3, p. 433-438, 2009. 
PIERCE, P. H. Australian tourism education: the quest for status. Available at: <www.haworthpress.com/web/JTTT>. Acess: Apr. 10, 2010.

PROYECTO TUNNING. Tunning educational structure in Europe. Informe final. 2003.

QIUMEI, F. Conformity of tourism education and constructing innovative education patterns/conformite de l'education de tourisme et construction des modeles de l'education innovative. Canadian Social Science, v. 3, n. 2, p. 31-33, 2007.

QUIROS TOMÁS, F. J.; DÍAZ FERNÁNDEZ, M. C. Operaciones y procesos de producción en el sector turístico: un recorrido visual. Sevilla: Mergablum. Edición y Comunicación, S. L., 2008.

RAYBOULD, M.; WILKINS, H. Over qualified and under experienced: turning graduates into hospitality managers. International Journal of Contemporary Hospitality Management, v. 17, n. 3, p. 203-216, 2005.

REAL DECRETO. Real Decreto 172/2001, de 23 de febrero, por el que se homologa el título de diplomado en Turismo del Centro Florida Universitaria, de Catarroja, adscrito a la Universidad de Valencia. BOE, n. 59, 9 mar. 2001.

. Real Decreto 1126/2003, de 5 de septiembre, por el que se establece el sistema europeo de crédito y el sistema de calificaciones en las titulaciones universitarias de carácter oficial y validez en todo el territorio nacional. BOE, n. 224, 18 sep. 2003.

. Real Decreto 55/2005, de 21 de enero, por el que se establece la estructura de las enseñanzas universitarias y se regulan los estudios universitarios oficiales de grado. Modificado por Real Decreto 1509/2005.

. Real Decreto 56/2005, de 21 de enero, por el que se regulan los estudios universitarios oficiales de posgrado. Modificado por Real Decreto 1509/2005.

. Plan de estudios de titulo oficial Universidad Illes Baleares grado en turismo de acuerdo con el Real Decreto 1393/2007 de 29 de octubre por el que se establece la ordenación de las enseñanzas universitarias oficiales. 2007.

RICO, M.; PADUREAN, L. Higher tourism education in English — where and why?. Tourism Review, v. 64, n. 1, p. 48-58, 2009.

RING, A.; DICKINGER, A.; WÖBER, K. Designing the ideal undergraduate program in tourism: expectations from industry and educators. Journal of Travel Research, v. 48, n. 1, p. 106-121, 2009.

RITZER, G. La Macdonalización de la sociedad. Barcelona: Ariel, 1996.

SANGPIKUL, A. Internationalization of hospitality and tourism higher education: a perspective from Thailand. Journal of Teaching in Travel \& Tourism, v. 9, n. 1-2, p. 2-20, 2009. 
SEVERT, D.; TESONE, D.; BOTTORFF, T.; CARPENTER, M. A world ranking of the top 100 hospitality and tourism programs. Journal of Hospitality \& Tourism Research, n. 33, p. 451-471, 2009.

SHELDON, P. et al. Tourism education futures - 2010-2030: building the capacity to lead. Journal of Teaching in Travel \& Tourism, v. 7, n. 3, p. 61-68, 2007.

SIGALA, M.; BAUM, T. Trends and issues in tourism and hospitality higher education: visioning the future. Tourism and Hospitality Research, v. 4, n. 4, p. 367-376, 2003.

STERGIOU, D.; AIRE, D.; RILEY, M. The evaluation of the teaching individual academics in UK's tourism higher education: developing a construct for teaching profiles. International Journal of Tourism Research, v. 5, n. 1, p. 62-67, 2003.

SZIVAS, E.; RILEY, M.; AIREY, D. Labor mobility into tourism. Attraction and satisfaction. Annals of Tourism Research, v. 30, n. 1, p. 64-76, 2003.

TRIBE, J. Research paradigms and the tourism curriculum. Journal of Travel Research, n. 39, p. 442-448, 2001.

. The philosophic practitioner. Annals of Tourism Research, v. 29, n. 2, p. 338-357, 2002.

. Tourism, knowledge and the curriculum. In: AIREY, D.; TRIBE, j. (Eds.). An international handbook of tourism education. Oxford, England: Elsevier, 2006. p. 47-60.

WATSON, S.; MCCRACKEN, M. No attraction in strategic thinking: perceptions on current and future skills needs for visitor attraction managers. International Journal of Tourism Research, v. 4, n. 5, p. 367-378, 2002.

WHEELER, D.; LANKFORD, S. Rethinking tourism education: what should schools teach? Journal of Hospitality, Leisure, Sport and Tourism Education, v. 5, n. 2, p. 25-35, 2006.

WTO (World Tourism Organization). Turismo en Iberoamérica, Panorama actual, UNWTO/Secretaría General Iberoamericana (Segib) 2009.

WTTC (World Travel and Tourism Council). Economic impact data and forecast. 2009 Available at: <www.wttc.org/eng/Tourism_Research/Economic_Research/index. php>. Access: Mar. 14, 2010.

ZHANG, W.; FAN, X. Tourism higher education in China: past and present, opportunities and challenges. Journal of Teaching in Travel \& Tourism, v. 5, n. 1-2, p. 117-135, 2005. 


\section{Sites}

$<$ http://eees.universia.es/historia/index.htm >

<http://estudis.uib.cat/grau/turisme/competencies.html>.

<http://estudis.uib.cat/grau/turisme/GTUR-P/>.

$<$ www.mec.es $>$.

$<$ www.ua.es/oia/es/f_titulaciones/turismof.html $>$.

<www.uah.es/universidad/espacio_europeo/>.

$<$ www.ulpgc.es/index.php? pagina =titulaciones \&ver=titulacion detalle\&codigo $=151 \_4013 \_40 \_00>$. 